\title{
IMPROVING THE ATTITUDE AND REACTION TOWARDS MUNICIPAL SOLID WASTE MANAGEMENT IN MOZAMBIQUE
}

\author{
AMAD H. A. GANI ${ }^{1}$, OLAIDE M. ADEROJU ${ }^{2}$, ANTÓNIO G. DIAS ${ }^{2} \&$ ANTÓNIO A. R. MONJANE ${ }^{1}$ \\ ${ }^{1}$ Universidade Pedagógica de Maputo (UPM), Mozambique \\ ${ }^{2}$ Department of Geosciences, Environment and Spatial Planning, Faculty of Science, University of Porto, Portugal
}

\section{ABSTRACT}

The understanding of a sustainable municipal solid waste (MSW) management plan requires proper education and awareness by all the stakeholders. Uncoordinated disposal pattern of MSW, nonchalant attitude of the authorities and stakeholders, weak legislation and policies among others have contributed to the increasing human health risk, greenhouse gas emissions, as well as the degradation of the environment at large. Currently, Mozambique is faced with the problems of indiscriminate dumpsites in most of its major cities. Hence, this study aims at enlightening the stakeholders on their roles towards a sustainable MSW management through an education and outreach model. The methodology employed in this study was an integrated concept with four main components, which includes principal actors, routes, procedures, and people. However, in conclusion, the integration of this conceptual model into the existing MSW management framework in Mozambique is likely to promote environmental consciousness amongst the people. Furthermore, aesthetic, pollution-free, as well as a sustainable environment is assured.

Keywords: education, environment, management, MSW, outreach, sustainability.

\section{INTRODUCTION}

The problem of municipal solid waste management (MSWM) has emerged as one of the trending environmental issues in the world, especially for developing countries. Aderoju et al. [1], stated that the world will continue to generate municipal solid waste (MSW) in high quantity and varieties as a result of rapid urbanization, industrial development and socioeconomic impact, which in turn has become an environmental issue that requires urgent attention by every nation. In a study by Nnaji and Utsev [2], it was reported that the overstretching of waste management facilities and the inability of waste management authorities, to cope with the volume of solid waste generated is associated with increasing urbanization in major cities. It is unfortunate that the standards of waste management are still poor and outdated in many developing countries, with poor documentation of waste generation rates and its composition, inefficient storage and collection systems, disposal of municipal wastes with toxic and hazardous waste, indiscriminate disposal or dumping of wastes and inefficient utilization of disposal site space [3].

The issues of creating awareness and proper education on MSW management and disposal, ethics plays a good role in attaining environmental sustainability. Aderoju et al. [4] suggested that MSW sensitization and environmental education programs should be carried out in both urban and the rural communities. Moreover, Jackson [5] reported that many people are unable to exercise deliberate choice because they find themselves locked into unsustainable patterns caused by habits, routines, lack of knowledge, institutional structures, inequalities in access, social expectations and cultural values. In many African communities, lack of awareness and proper education on integrated waste management has contributed to the pattern of disposal of MSW and poor management practices. Several studies have reported that many African cities are still deficient in the proper management of their solid waste. For instance, many Mozambican cities are no exception to this whereby most of their 
MSW are being buried, burnt, or disposed haphazardly in the environment. According to INE (Instituto Nacional de Estatistica de Moçambique) [6], 46\% of the Mozambican population engage in the combustion of MSW within the perimeter of their homes, $23 \%$ bury, while $19 \%$ dispose of their MSW on open land. Concerns were raised in the past by the WHO [7] on poor sanitation and unsatisfactory waste management in African societies in a way to mitigate human health risk. According to the IPCC report of the 12th season of the intergovernmental panel on climate change [8], methane emission from landfill was estimated to account for 3\% to $19 \%$ of the anthropogenic sources in the world. Moreover, UNWSSD [9] reported that the theme of the World Summit on Sustainable Development in Johannesburg, South Africa was on waste minimization, recycle, reuse and safe disposal of waste to minimize pollution of the environment.

Overcoming public attitudes and unsustainable behaviour requires effective communication, a broad public understanding of the requirements of solid waste management and active participation of all relevant stakeholders throughout all project stages [10]. One of the merits of active participation was reported by Rousta and Dahlén [11], that inhabitants' participation in waste separation schemes seems crucial for the improvements needed to achieve a better ambitious material recycling goal. According to Sallwey et al. [12], it was reported that illiteracy and low education levels pose a challenge for waste management services and awareness campaigns. However, the initiatives taken by the international stakeholders are often ineffective due to poor coordination and thus have not fostered much sustainable changes in waste management [13]. The transformation of the society to gain environmental and sanitary awareness is dependent on the level of education and outreach. The attitude of the Mozambican people in the major cities on waste disposal pattern and sanitation ethics has become an overburden on the authorities and the communities at large as it adverse effects, as reported by countless researchers, threaten human health risk. In this view, the study aims at enlightening the stakeholders on their roles towards a sustainable MSW management through an education and outreach model. This study is likely to bridge the gap of awareness on environmental ethics and solid waste management in the major cities in Mozambique. Furthermore, the study is likely to improve the mentality, behavior and practice of the inhabitants of the communities towards attaining a sustainable and aesthetic environment.

\section{STUDY AREA}

The Republic of Mozambique is located on the latitudes $10^{\circ} 27^{\prime} \mathrm{S}$ and $26^{\circ} 52^{\prime} \mathrm{S}$ and longitudes $30^{\circ} 12^{\prime} \mathrm{E}$ and $40^{\circ} 51^{\prime} \mathrm{E}$, with a surface area of $799,380 \mathrm{~km}^{2}$ [14]. Also, it is bordered on the north by Tanzania, on the west by Malawi, Zambia, Zimbabwe, and South Africa, and on the south by Swaziland and South Africa, with its territory bordered by the Indian Ocean, in a span of about 2,515 km to the east. Mozambique has a population density (see Fig. 1), that is predominantly a rural, with an estimated population at 27,909,798 inhabitants [6]. However, according to Muchangos [14], a little above $23 \%$ of the entire population resides in urban areas. The economy of Mozambique is dependent on agriculture, in which subsistence type of farming is the major practiced.

The geographical situation and history of this country marked by various migratory processes result in a heterogeneous population group, with multicultural and multiethnic characteristics. Furthermore, for economic reasons, Mozambique is a member of the Southern African Development Community (SADC) group of countries. 


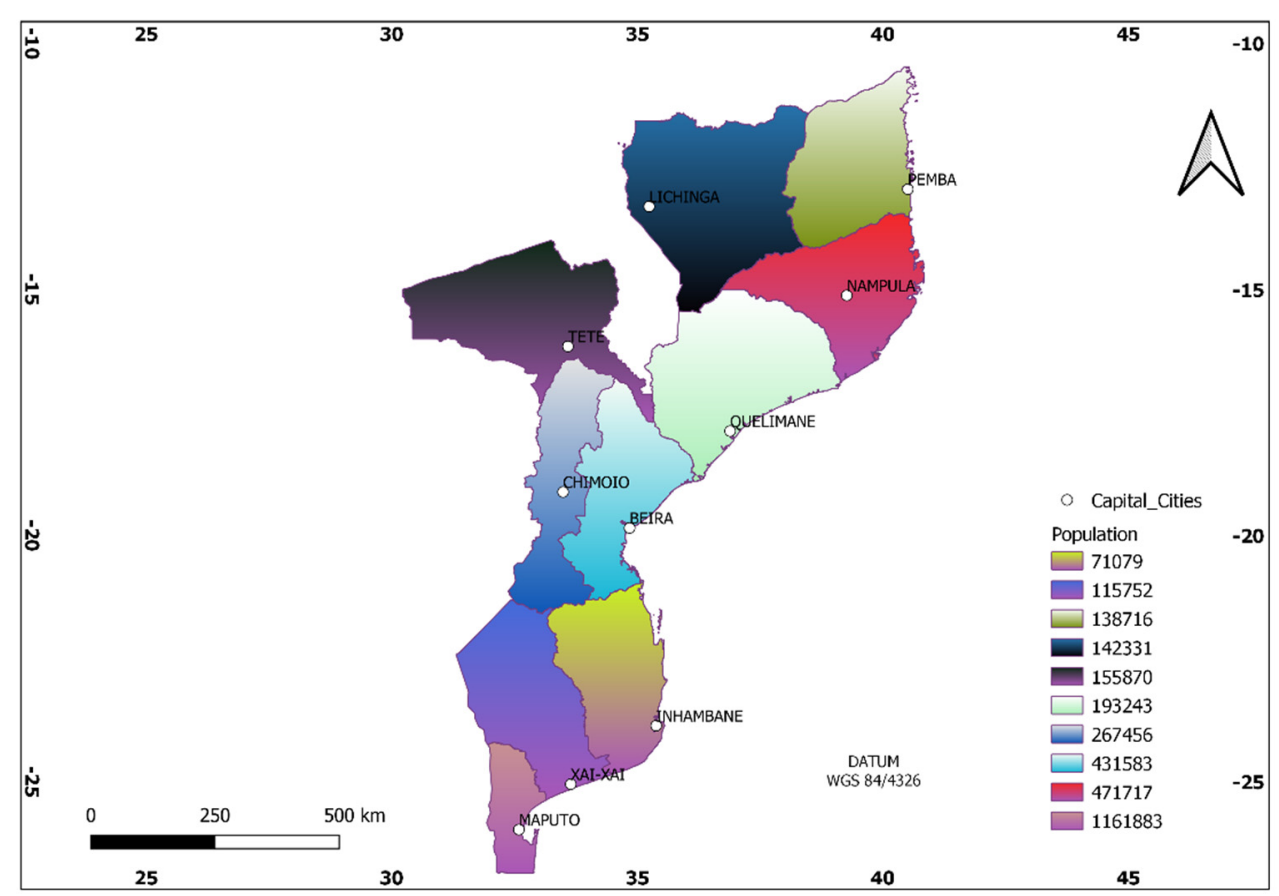

Figure 1: Population density map of Mozambique. (Source: Adapted from [6].)

\section{STATUS OF MSW MANAGEMENT IN MOZAMBIQUE}

The ideal practice in Mozambique on MSW management is for MSW to be collected, transported, and deposited in the municipal open containers by a public-private partnership, managed entirely by municipal city agencies, municipal town's agencies and govern of district administrations.

The national collection coverage ranges between 40-65\% [15]. However, according to Tas and Belon [16], it was reported that Maputo's collection coverage increased to about $82 \%$ as compared to other major cities. Hence, the collection of waste from the local dumpsites in the inner city of Maputo increased profoundly from 76 million kilograms in 2007 to 253 million kilograms in 2014 [12]. However, there are setbacks affecting this effective and efficient plan includes, soft implementation of policies, low coverage of MSW collection, low financial support, absence of modern technological equipment, and ultimately, low awareness and education on waste management initiative. The reality of the environmental issues caused as a result of poor MSW management program in Mozambique is as shown in Fig. 2. INE [6] reported that at the national level, the rate of collection of household waste by municipal or administrative authorities is $7.6 \%$, while $1.1 \%$ is collected by private companies.

Also, MITADER (Ministério da Terra, Ambiente e Desenvolvimento Rural) [17] showed that Maputo city produces the most MSW, with 415,005 tons per year of the country's total production and Inhambane city produces the least, with 17,520 tons per year (see Fig. 3). Individual municipalities, and private companies under a contract with the authorities also collects MSW from markets, restaurants, and other larger clusters in the community. 


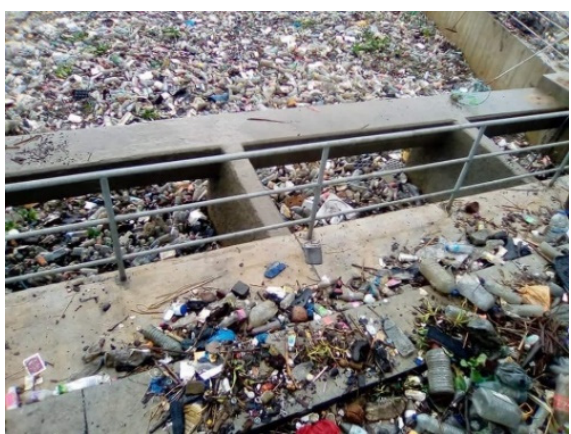

(a)

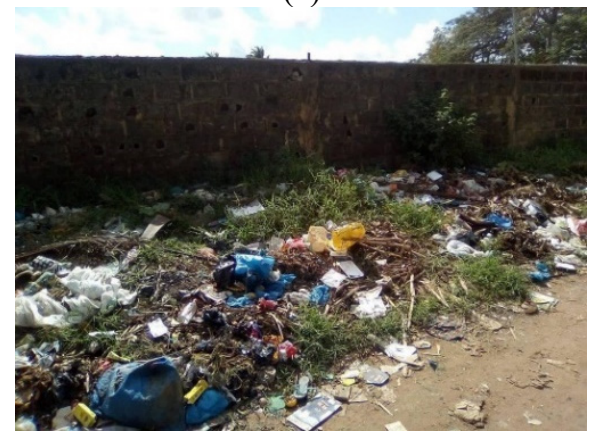

(c)

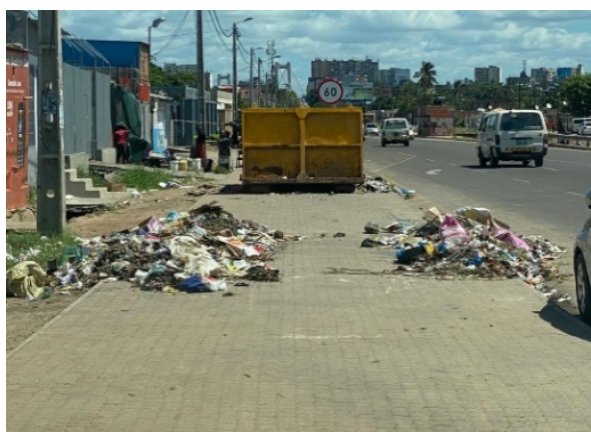

(b)

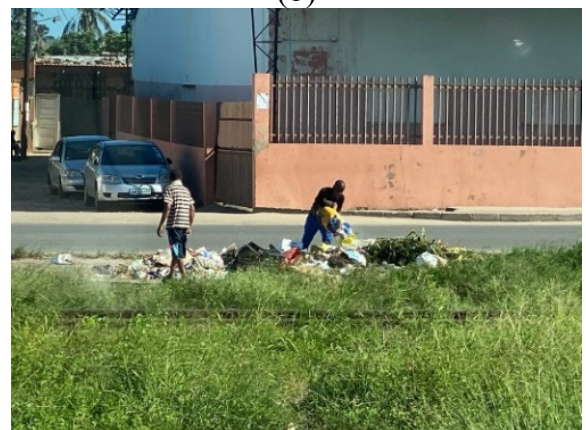

(d)

Figure 2: MSW reality in Mozambique. (a) Drainage dumping; (b) Street littering; (c) Illegal dump site; and (d) Indiscriminate dumping. (Source: Authors' field investigation.)

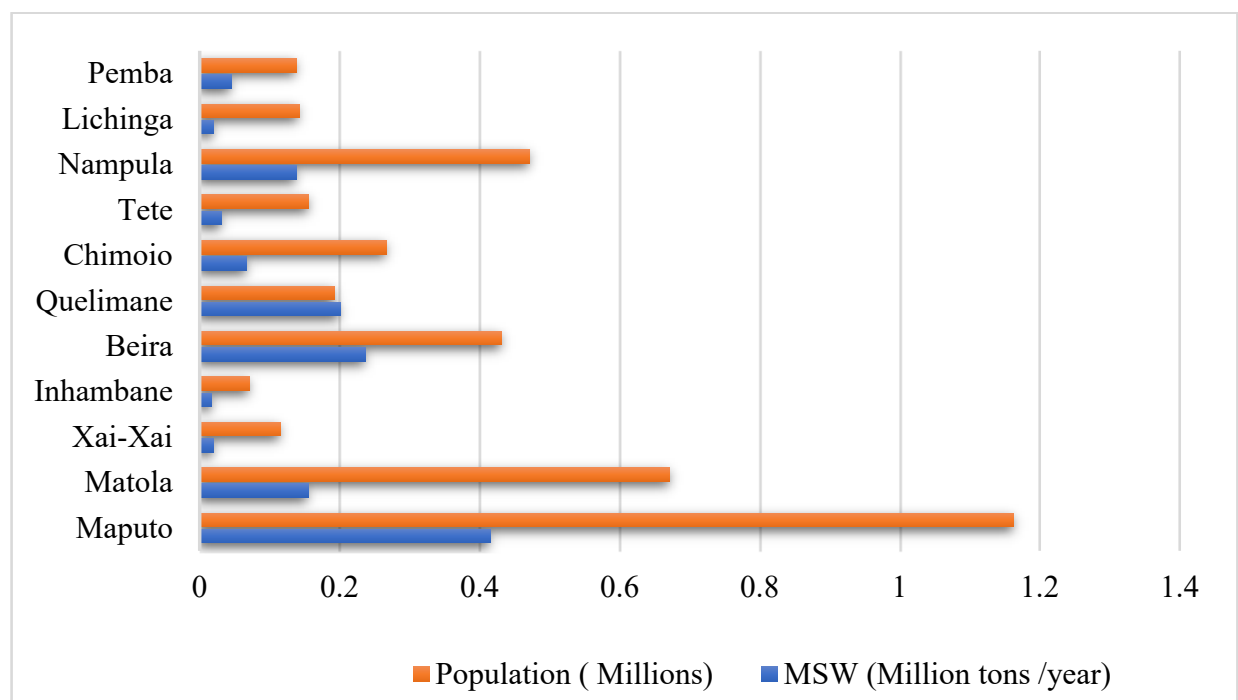

Figure 3: MSW generation in the capital cities of Mozambique. (Source: Adapted from [17].) 
However, private companies, and few NGOs such as AMOR (Associação Moçambicana de Reciclagem) among few engage in waste segregation into waste categories like paper/cardboard, glass, plastic, metals, and others, for profit purposes. Cart pushers collect waste in places where there is no car access due to the absence of roads. In addition, the informal sector of the MSW management is clearly involved in the picking valuable and reusable materials from dumpsites for the purpose of recycling and useable. This is usually carried out by waste pickers otherwise known as "catadores", who earn their livelihood by collecting valuable materials from dumpsites and other places and selling it to vendors in the recycling industry.

The integration of waste pickers into the MSW management cycle is very significant as their contribution is likely to improve the recycling of MSW recycle in the many cities in other hand to clean the cities, helping the government. Again, it was reported in AMOR [18], and Buque and Ribeiro [19] that in a way to support informal collection, AMOR installed Eco-Points throughout Maputo to purchase recycled goods from private persons and waste pickers and resell to the recycling sector. Sallwey et al. [12] also reported that AMOR estimated that approximately 350 waste pickers sold about $300,000 \mathrm{~kg}$ of waste per month to these collection points in 2011.

\section{EXISTING MSW MANAGEMENT LEGISLATIONS IN MOZAMBIQUE}

The existing legislation and policy framework for solid waste management in Mozambique is mainly concerned with the requirements for licensing and auditing of public and private institutions involved in solid waste management [12]. The management of MSW remains the responsibility of the municipals, townships or district administrations. However, in the rural communities, particularly, MSW is usually managed by individuals, which is characterized by open dumping, burying and combustion which has a negative impact on human health and the environment at large. This prompts the government of Mozambique, to issue Decree No. 94/2014, in all the major cities on MSW management [20]. Although there is an existing Master Plan for the MSW in Maputo, the capital city of Mozambique, which is "Resolution No. 86/AM/2008 of 22 May 2006 [21], MSW Cleaning Posture in Maputo Municipality". This document defines the Maputo City cleaning system, integrating the MSW screening and management of the components. It applies to all public and private activities that directly or indirectly influence the cleanliness component of the municipality. It aims to establish the framework of general principles and standards of the MSW cleaning system.

\subsection{Decree No. 94/2014, of 31 December, Regulation on Municipal Waste Management}

The Decree No. 94/2014 [20] was established as a guideline to address one of the most serious urban environmental problems in Mozambique. This decree at the national level sets forth its principles, objectives, instruments, as well as guidelines regarding integrated solid waste management which include hazardous waste, the responsibilities of people and the government. The two most significant sections of this Decree No. 94/2014 [20] are Articles 4 and 8, respectively. Article 4, states that "all public and / private entities engaging in MSWM should develop and implement an integrated solid waste management plan that is managed based on the principles of the waste management hierarchy". Article 8 further states that it is imperative to promote good municipal solid waste management practices (recycling, composting, selective collection and landfill), in coordination with other public institutions, civil society organizations and the private sector. It is the obligation of public or private entities that carry out activities related to waste management to draw up a waste management 
plan they manage before the start of their activity. The mandate of these public and / private entities includes solid waste plans; semi-annual solid waste inventories and reporting systems; environmental monitoring and inspection; environmental education and the national register of hazardous waste operators.

\section{STRUCTURE OF MSW MANAGEMENT IN MAPUTO CITY}

The management of MSW in Maputo city utilizes a specified framework (see Fig. 4), whereby the Maputo City Municipal Council (MCMC) is responsible for sweeping and cleaning the municipal streets and the collection of all MSW produced in the city. The per capita generation of MSW per individual was estimated at $1 \mathrm{~kg}$ per person daily in the inner city in Maputo compared to $0.56 \mathrm{~kg}$ per person daily in the suburban areas [22].

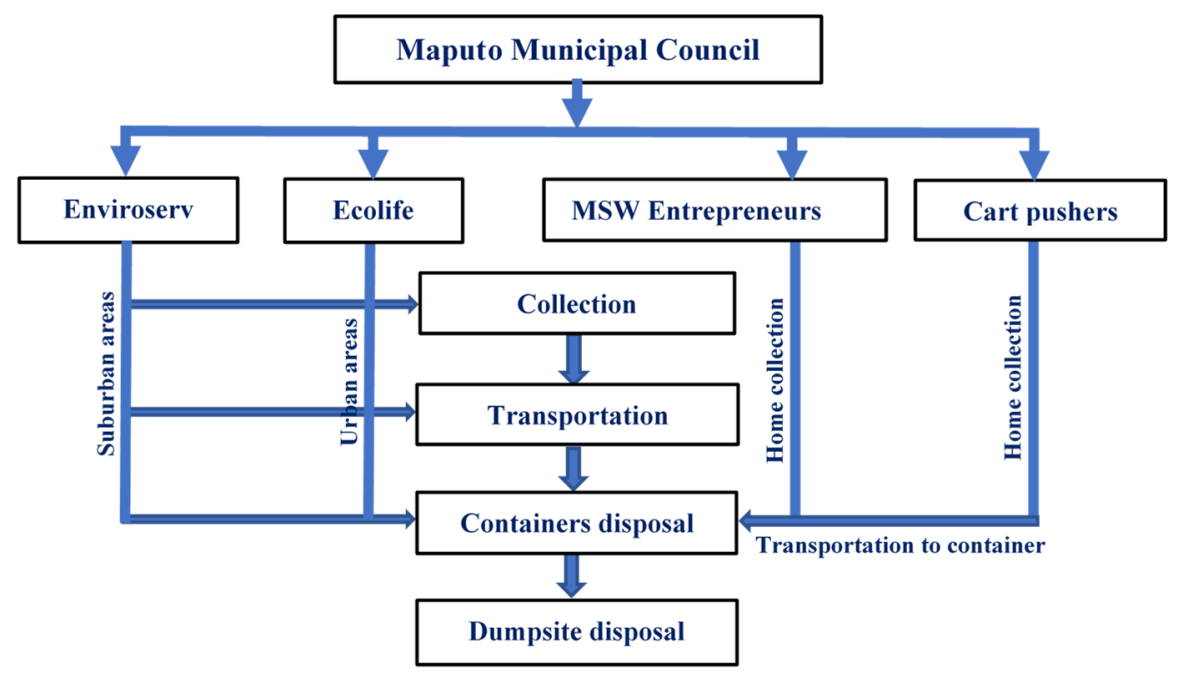

Figure 4: MSWM structure in Maputo city.

The MCMC through public private partnership (PPP) engaged two companies which include: the Ecolife, which collects wastes in the urban zones, and Enviroserv, which collects wastes in the suburban zones, particularly in markets, and transport terminals [23]. These two companies utilize 1.1 cubic meters of plastic containers with lids (Ecolife), and 6 to 10 cubic meters of metal containers (Enviroserv) and transports the collected MSW for safe disposal at the municipal Hulene dumpsite. It is unfortunate that the collection services in Maputo varies according to the level of income based on the income level and status of the neighbourhood. The MSW entrepreneurs also known as private micro-enterprises, licensed to collect household wastes, representing public-private partnerships (PPP), are licensed to collect at restaurants and other high-waste production sites. These private micro-enterprises also collect according to requests from any individual or institution that has enough MSW to dispose of if they pay the company for transportation costs. Also, the private microenterprises do not have the jurisdiction to transport the MSW collected to the municipal dumpsite. Instead, the MSW collected is transported to a private dumpsite to separation into different components for the sale of valuable materials. In addition, there exist cart pushers who are individual waste collectors in suburban areas that are not within the reach of the companies collecting for the MCMC. The cart pushers are also regarded as a member of the 
informal sector in the waste management chain. They are identified with their locally built two-wheeled traction vehicles used for the collection of MSW from homes with no access roads to MSW pick-up trucks. Fig. 4 shows the MSW management structure in Maputo.

\section{CONCEPTUAL MODEL FOR EDUCATION AND OUTREACH ON MSW MANAGEMENT}

The conceptual framework (Fig. 5) is to change the attitude and actions of the Mozambican people to achieve a sustainable waste management program. The proposed conceptual model on education and outreach on MSW management is a tool to enlighten the people of the society on waste disposal ethics, solid waste management benefits, and stakeholders' participation to attain sustainability in the waste management sector. This model is a composition of the four components, which include: principal actors, route, procedure, and people. The model is further expanded in Fig. 6 for proper understanding.

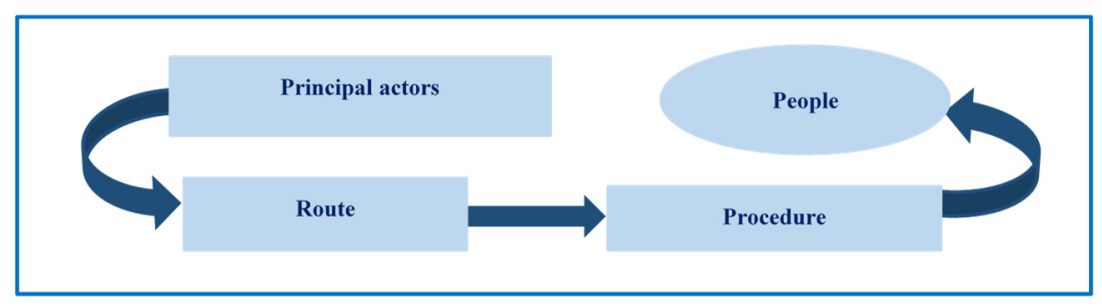

Figure 5: Conceptual framework.

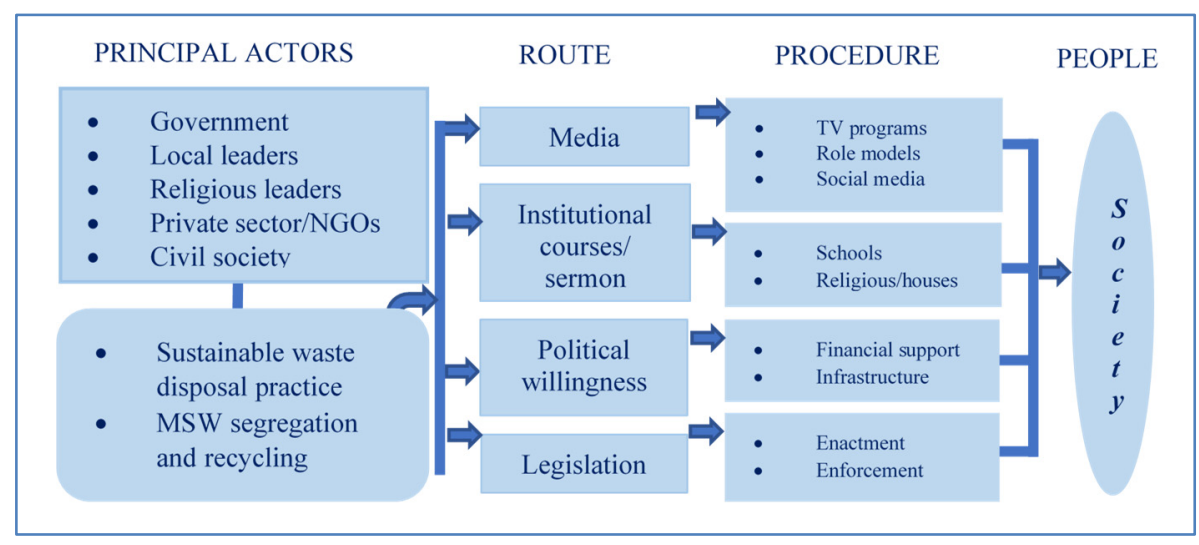

Figure 6: Education and outreach framework. (Source: Adapted from [4].)

Fig. 5 shows the main components of the education and outreach framework which include principal actors, route, procedure and people. The main objective of the principal actors in this study is to enlighten the people on environmental ethics and waste management practices and its benefits. The principal actors comprise of the government, local leaders, religious leaders, private sector, NGOs, as well as the civil society (see Fig. 6).

The principal actors convey their messages on and waste management practices with lots of emphasis on the benefits through some routes (see Fig. 6). This routes where the education 
and awareness are conveyed includes through the media, institutional courses/sermon, political willingness and legislation. The media remains one of the fastest ways of dissemination information to the public because people want to be well informed, learn, and perhaps satisfy their leisure time with pleasure on the current trends locally and globally. Also, information like is conveyed using different procedures with role models using their social media platforms to educate the people, demonstration or pronouncement in movies/ cartoons, as part of the lyrics in music, as radio adverts and broadcast and many more. Today, social networks play an important role in disseminating information to both urban and rural communities. Considering that most of the rural population is illiterate, music, radio broadcast and images on billboards is likely be the best way to disseminate information.

Furthermore, another way of educating the society on environmental ethics and waste management practices and its benefits is simply by introducing it as a subject/course are another in schools (elementary, high and tertiary). The recipient of such education in schools is likely to reflect in their perception and practice. This type of education can also be extended to orphanage homes, and religion houses (churches, mosques, temples) as sermon where the phrase "cleanliness is next to godliness" is constantly uttered during counselling.

Political willingness to support education and outreach programs on environmental ethic on waste disposal practices and waste management by the government will be a positivity for any nation's sustainable development. With the support of the government, there will be commitments by providing support to the campaign through financial support, employment of competent staff to educate the people, providing basic infrastructures and assured equality in services will be provided. For instance, MSW infrastructures and operation will not be focused only in the high-income districts, but it will rather be for all the inhabitants.

Again, the legislative arm of the government needs to see the importance to supporting environmental development concept, as weak policies and legislation have been detrimental to the environmental and the society. Hence, the existing legislation can leverage on or rather create new laws that supports environmental consciousness and waste management with full implementation and enforcement. It is important that the people in the society are aware of such laws. Nevertheless, it must be made known that defaulters are likely to face heavy penalty.

The education and outreach program benefit the society to enlighten and build a sustainable attitude towards the environment and particularly MSW management. The people of the society are usually governed or coordinated by the principal actors of the society. Hence, the use of different routes of communication is used to disseminate information to the society. It is expected that with such education and outreach program on environmental ethics and MSW management disposal practices, the horizon of the people is broadened on sustainable MSWM and disposal practices to attain an environment that is free of pollution and human health risk for the future generations.

\section{CONCLUSION}

In Mozambique, the weak policies and legislation of MSW management are mere pronouncement, non-implementation, and low enforcement, has contributed to the degradation of the urban environment. However, the creation of awareness and education on environmental ethics, and sustainability, enabling participatory management of MSW, to the people will take some time to produce the desired effect. A better environmentally educated society tends to understand that environmental awareness contributes to environmental sustainability and, consequently, it mitigates the human health risk and promote an aesthetic environment. This study has shown and discussed a conceptual model that emphasized that MSW management is not solely the responsibility of the government but a collective 
responsibility of all stakeholders to enhance the building of a sustainable environment. Hence, the outreach and education programs in MSW management should be a continuous and practicable exercise for sustainable development of the society. Also, it was deduced from the conceptual model that MSW management should begin with civil society and municipalities to establish an integrated solid waste management mechanism that are best suited to each of the capital cities and whole Mozambique. Again, synergy between principal actors and the society is likely to drive urban development of cities and towns.

In recommendation, the government should give priority to the environment by ensuring that solid waste management policies and legislation are revived, implemented and enforced in all arms of the government. The sensitization programs of solid waste management should not be resident in the cities alone but rather be extended to the rural communities continuously and not to be abolished by any change in government so that a good environmental consciousness is built and passed on to the future generation. The rate of urbanization in Mozambique requires adequate planning and efficient strategies in the management of the MSW generation, hence this study is likely to be the baseline line strength of such MSW management programs, especially with the channels of education, communication and participation practice.

\section{ACKNOWLEDGEMENTS}

Our appreciate goes to the Director of Natural Science and Mathematics, Universidade Pedagógica de Maputo, Maputo, Mozambique for his technical support and opportunities. Also, we truly appreciate the support of the Director of the Environmental Science and Technology Program, Faculty of Sciences, University of Porto, Portugal during this research.

\section{REFERENCES}

[1] Aderoju, O.M., Dias, G.A. \& Gonçalves, A., A GIS-based analysis for sanitary landfill sites in Abuja, Nigeria. Environment, Development and Sustainability, 2018. https://doi.org/10.1007/s10668-018-0206-z.

[2] Nnaji, C. \& Utsev, T., Climate change and solid waste management: A balanced assessment. Journal of Sustainable Development in Africa, 13(7), pp. 17-34, 2011.

[3] Kadafa, A.A., Latifah, A.M., Abdullah, H.S. \& Sulaiman, W.N.A., Current status of municipal solid waste practise in FCT, Abuja. Research Journal of Environmental and Earth Sciences, 5(6), pp. 295-304, 2013.

[4] Aderoju, O.M., Dias, A.G. \& Guimarães, R., Building an integrated perception and attitude towards municipal solid waste management in Nigeria. Wastes 2015: Solutions, Treatments and Opportunities, eds C. Vilarinho, F. Castelo \& M. Russo, CRC Press, pp. 7-12, 2015.

[5] Jackson, T., Motivating Sustainable Consumption. A Review of Evidence on Consumer Behaviour and Behavioural Change, Sustainable Development Research Network (SDRN), 2005.

[6] Instituto Nacional de Estatística de Moçambique (INE), Apresentação dos Resutados do IV Recenseamento Geral da População, Censo de 2017. www.ine.gov.mz. Accessed on: 15 Dec. 2019.

[7] WHO, Report on Environmental Sanitation in African Region; Trend and Analysis, The 43rd Session of the World Health Organization Committee for Africa, Gaborone, Botswana, Sep. 1993, AFR/RC43/R2.

[8] IPCC, Solid waste disposal. Guidelines for National Greenhouse Gas Inventories, Volume 5: Waste, eds R. Pipatti \& P. Svardal, P, Geneva, Switzerland, 2016. 
[9] UNWSSD, World Summit on Sustainable Development, Implementation Plan: Johannesburg Declaration Report, United Nations Publications, Mar. 2002. www.un.org.esa/sustdev/documents/johannesburg\%20Declaration. Accessed on: 14 Dec. 2019.

[10] Schübeler, P., Conceptual Framework for Municipal Solid Waste Management in LowIncome Countries, eds K. Wehrle \& J. Christen, UNDP/UNCHS/World Bank/SDC Collaborative Programme on Municipal Solid Waste Management in Low-Income Countries: St. Gallen, Switzerland, 1996.

[11] Rousta, K. \& Dahlén, L., Source separation of household waste, technology and social aspects. Resource Recovery to Approach Zero Municipal Waste, eds M.J. Taherzadeh \& T. Richards, Boca Raton: CRC Press, pp. 61-77, 2015.

[12] Sallwey, J., Hettiarachchi, H. \& Hülsmann, S., Challenges and opportunities in municipal solid waste management in Mozambique: A review in the light of nexus thinking. AIMS Environmental Science, 4(5), pp. 621-639, 2017.

DOI: 10.3934/environsci.2017.5.621.

[13] Ferrari, K., Gamberini, R. \& Rimini, B., The waste hierarchy: A strategic, tactical and operational approach for developing countries - The case study of Mozambique. Int. J. Sustainable Dev. Plan, 11, pp. 759-770, 2016.

[14] Muchangos, A., Moçambique, Paisagens e Regiões Naturais, Tipografia Globo, 1999. 01048/FBM/93, República de Moçambique, Maputo.

[15] Karani, P. \& Da Costa, J., The role of knowledge in improving waste management for sustainable development: The case of Maputo Mozambique, 2007. www.environmentalexpert.com/Files/0/articles/16550/MozambiqueWasteManageme nt--PatrickKarani--article2.doc. Accessed on: 18 Nov. 2019.

[16] Tas, A. \& Belon, A., A comprehensive review of the municipal solid waste sector in Mozambique, 2014. www.associacao-mocambicana-reciclagem.org. Accessed on: 18 Nov. 2019.

[17] MITADER (Ministério da Terra, Ambiente e Desenvolvimento Rural), Statistical data of municipal waste management in major cities of Mozambique, 2019. www.ruralmoc.gov.mz/. Accessed on: 12 Dec. 2019.

[18] AMOR, Project Catalogue, 2013. www.associacao-mocambicana-reciclagem.org. Accessed on: 21 Nov. 2019.

[19] Buque, L.I.B. \& Ribeiro, H., Overview of the selective waste collection with pickers in Maputo Municipality, Mozambique: Challenges and Perspectives. Saúde Soc. 24, pp. 298-307, 2015.

[20] Decree No. 94/2014, Regulation on Municipal Waste Management, Maputo, 31 Dec. 2014.

[21] Resolution No. 86/AM/2008, Posture of Cleaning of Solid Municipal Waste in the Municipality of Maputo, Maputo, 22 May 2006.

[22] Stretz, J., Economic instruments in solid waste management. Eschborn, Germany: Deutsche Gesellschaft für Internationale Zusammenarbeit (GIZ) GmbH, 2012. www.giz.de/de/downloads/giz2012-en-economic-instruments-mozambique.pdf.

[23] Federal Ministry for Economic Cooperation and Development, Solid Waste Management Master Plan (SWMMP). Maputo, 2008. www.giz.de/en/downloads/ giz2012-en-economic-instruments-mozambique.pdf. 